\title{
Value-relevance of disclosure: risk factors and risk management in Brazilian firms*
}

\author{
José Glauber Cavalcante dos Santos \\ (D) https://orcid.org/0000-0002-7971-3542 \\ Email: jglauber_cont@hotmail.com \\ Antonio Carlos Coelho ${ }^{1}$ \\ (D) https://orcid.org/0000-0002-4126-0955 \\ Email: accoelho47@gmail.com
}

1Universidade Federal do Ceará, Faculdade de Economia, Administração, Atuária e Contabilidade, Programa de Pós-Graduação

em Administração e Controladoria, Fortaleza, CE, Brazil

Received on 07.04.2017 - Desk acceptance on 08.07.2017 - 3rd version approved on 02.23.2018 - Ahead of print on 07.26.2018

Associate Editor: Eliseu Martins

\begin{abstract}
This study investigated whether the disclosure in accounting reports of information on risk and its management affects, at the margin, firm valuations in the Brazilian capital market. It questioned the existence of value relevance in the disclosure of information related to risk factors and risk management structures. The importance of the topic arises from the documentation that disclosure on risk factors plays a statistically significant role in valuing firms in a context marked by economic and political uncertainty, as is the case of the Brazilian market. The findings confirmed that information about risk shows informational relevance for firm valuations. Information on risk management in a firm, in turn, was not shown to be significant in terms of affecting company share valuations. The investigation of detailed reports with different risk factors indicated that individualized information shows different degrees of relevance for company valuations. It is inferred that the disclosure of risk factors affects the perception of investors, who also base their estimates of return on the availability and detail of such information. It is also observed that information on risk management structure was not shown to be value relevant; moreover, few firms published information on the establishment of this type of entity in their management structures. The residual income valuation (RIV) model (Ohlson, 1995) was applied using regressions with panel data estimation related to the three years covering 2012 to 2014. The sample, which was randomly delimited, was formed of 100 companies. The data on disclosure of risk and disclosure of risk management were collected from the companies' Reference Forms, available from the website of the São Paulo Stock, Commodities, and Futures Exchange (BM\&FBOVESPA). As an impact on the area of knowledge, broader discussions are expected regarding the utility of disclosure on the topic related to risk factors and the existence of a specific body responsible for risk management in firms, according to investors' perceptions. It also contributes by providing evidence about the quality of disclosure related to risk (factors and management) and the perception of the capital market regarding the informativeness and relevance of such elements.
\end{abstract}

Keywords: risk disclosure, risk management, informational asymmetry, value relevance of disclosure, residual income.

Correspondence address

José Glauber Cavalcante dos Santos

Universidade Federal do Ceará, Faculdade de Economia, Administração, Atuária e Contabilidade, Programa de Pós-Graduação em

Administração e Controladoria

Avenida da Universidade, 2431 - CEP 60020-180

Benfica - Fortaleza - CE - Brazil

* Paper presented at the XI ANPCONT Congress, Belo Horizonte, MG, Brazil, June 2017. 


\section{INTRODUCTION}

This study examines the informational relevance attributed to the disclosure of information on risk factors associated with firms and to the reporting on the existence of risk management. This disclosure is expected to be relevant for investors, since it indicates the magnitude of the expected losses - possible and probable - of a business, and reports management efforts to mitigate their expected negative effects. The reporting of risks can explain unexpected movements in share prices, due to the market's perception regarding the persistence of the earnings of firms that are more or less susceptible to specific risk factors (Jorion, 2002; Lim \& Tan, 2007). The Brazilian market is an environment that is suitable for analysis, since it involves an emerging economy, characterized by an environment with low legal protection of investors, who feel vulnerable to potential expropriations (Terra \& Lima, 2006). A report on sources of risk to the business and on the efforts to manage risk factors would contribute to the firm valuation process, enabling accurate estimates, reducing cost of capital, and thus attracting new investors and increasing the market liquidity of its securities.

In Brazil, the disclosure of risk factors is regulated by Brazilian Securities and Exchange Commission Instruction n. 480 (CVM, 2009), in the item about "risk factors that can influence investment decisions" to be reported by firms in the Reference Form. This would describe risk factors linked to the company itself, to the controller, to the shareholders, to the controlled parties, suppliers, and customers, to the operating sector, to the regulation, and to operations in foreign countries. With regards to the information on risk management, it is also imperative for the company to report on the existence of a specific body in the administrative structure.

The value relevance of disclosure of specific information has been the target of various studies, as mentioned by Brown, Lo, and Lys (1999). The residual income valuation (RIV) model provides support for valuing firms depending on residual incomes and other information that would represent relevant events not yet incorporated into the accounting information, but that could affect future earnings (Lopes, Sant'Anna \& Costa, 2007; Ohlson, 1995). Thus, using the Ohlson model (1995), the residual income of the subsequent period depends on the residual income of the previous period, which is guaranteed by the assumption of the linear informational dynamic (LID); the model therefore defines that predicting future abnormal income is based on this assumption and on the effects of this other information (Coelho \& Braga, 2008).
According to Ball and Brown (1968), accounting incorporates various components when generating an information set and, as a result, net income covers an aggregate of these components, which are not homogenous. However, it is known that net income does not incorporate all the information capable of causing a change in expectations, altering the behavior of the decision maker (Beaver, 1968) and thus affecting the firm's valuation. With the Ohlson model (1995), it is possible to empirically verify whether "other information" available in the market, not recognized by the accountants when calculating accounting income due to the current precepts in the accounting standards, is capable of altering the estimation of future abnormal income and, consequently, the value of the firm.

So, the Ohlson model (1995) is applied to evaluate Brazilian firms and test whether the disclosure regarding risk factors and management, in "other information" not captured in the accounting numbers, can be considered a relevant item for defining the price and return of firms. For Kimura and Pereira (2005), it is possible to accept that this information can prove to be critical for determining company value, given that the sources of uncertainty can affect a firm's upcoming results, meaning practices that aim to manage risk and their disclosure can improve the estimated value of the business.

Risk management includes the disclosure of information on risk to reduce informational asymmetry between managers and investors, which would generate a more efficient allocation of resources between the economic agents in the market. For this reason, Solomon, Solomon, Norton, and Joseph (2000) define risk management as an essential practice for the maximization of shareholder value, based on the premise that establishing its reporting to the market gives businesses increased chances of success and supports the investment decisions of shareholders.

In his valuation model, Ohlson (1995) does not specify which relevant events can compose "other information", but by considering them he recognizes that there is a set of information capable of affecting firm value that is not calculated by the accounting method, given that this information is available to the market and it can substantially alter investor expectations (Ball \& Brown, 1968; Beaver, 1968).

This information, which is forward-looking in character, is not incorporated into the accounting income for the period, but as it is realized, it forms part of the income in future periods, thus explaining residual 
incomes. Investors are interested in company value, which can be understood based on the present value of future cash flows discounted at the risk adjusted rate. The current performance of a firm, reflected in its financial statements, should not be the only source of information for valuing the company (Kothari, 2001).

What would explain the existence of value relevance in the information on risk is the fact that there is information asymmetry in the market. As management has discretion and decides what information will be published, its release would affect perceptions of the relevance and quality of the disclosure; that is, these communications work as signalers of the probability of future events. Thus, it is conjectured that the understanding of the risk factors a company is subject to, and their management, would be presented as "other information", including potential explanatory variables for the value of the firm (Chung, Judge \& Li, 2015; Edirisinghe, Gupta \& Roth, 2015; Kimura \& Pereira, 2005; Solomon et al., 2000).

Based on this discussion, and considering the importance of studies that have examined the value relevance of accounting information (Kothari, 2001) and the propensity that sources of uncertainty that are amenable to disclosure have to influence investor decision making (Silva, Albuquerque, Marcelino \& Quirós, 2015), we have the following question: is the disclosure of information in accounting reports regarding risk factors and the existence of risk management bodies value relevant in the Brazilian capital market?

Based on the literature review concerning the subject in question, both international studies (Abraham \& Cox, 2007; Beretta \& Bozzolan, 2004; Cornaggia, 2013; Dobler, 2008; Edirisinghe et al., 2015; Jorion, 2002; Lim \& Tan, 2007; Linsley \& Shrives, 2006; Moumen, Othman \& Hussainey, 2015; Solomon et al., 2000) and Brazilian studies (Alves \& Cherobim, 2009; Alves \& Graça, 2013; Beuren, Dallabona \& Dani, 2011; Cardoso, Mendonça \&
Riccio, 2004; Carvalho, Trapp \& Chan, 2004; Cherobim \& Alves, 2006; Fernandes, Souza \& Faria, 2010; Peleias, Silva, Guimarães, Machado \& Segreti, 2007; Zonatto \& Beuren, 2009) were found that have addressed the theme of the disclosure of risk and its management, mostly evaluating the content of the disclosure and its determinants.

This same literature highlights that market, financial, corporate, strategic, technological, and environmental (legal, political, and economic) risks are those most often identified and reported by firms. Only Moumen et al. (2015) address the relevance of the voluntary qualitative reporting of risk in financial reports. For Solomon et al. (2000), risk management is essential for maximizing shareholder wealth and reducing the chances of sharp changes in income. The study stands out because it investigates the value relevance of the normative reporting of nine risk factors and of the existence of management of the sources of uncertainty.

The aim is to support the field of study that investigates the value relevance of information on risk and its management, which are, a priori, considered critical for valuing firms. Few studies have considered the moderating intermediation channels in the relationship between risk and its disclosure and company value, or they suggest results that are not yet conclusive (Cornaggia, 2013; Edirisinghe et al., 2015; Kimura \& Pereira, 2005; Solomon et al., 2000).

Besides contributing to strengthening the field of studies that examines the relevance of disclosure for decision making on value formation, this study provides evidence of the role played by disclosure on the management of sources of uncertainty as firm-distinguishing factors in relation to informational asymmetry. Managerially, the results and conclusions of the study can help managers with regards to reporting information that is considered to be critical for maximizing firm value and affecting investor behavior.

\section{THEORETICAL FRAMEWORK AND DEVELOPMENT OF THE HYPOTHESES}

Amorin, Lima, and Murcia (2012) mention that accounting information represents an important useful variable for estimating companies' future cash flows and even for evaluating their risk. These positions indirectly support the concept that the reporting of information in relation to risk can favor firm valuations, given that the definition of risk covers the inability to predict cash flows. So investors will decide to invest resources in firms based on expectations regarding the materialization (or risk) of future results that maximize their wealth (Fisher \& Hall,
1969). The studies by Jorion (2002), Lim and Tam (2007), and Moumen et al. (2015) show that the reporting of the risks associated with firms is informative and is reflected in their valuations.

According to Elshandidy, Fraser, and Hussainey (2013), the publishing of information concerning risk is decisive for evaluating future cash flow generation by a firm, because investors identify the effects of factors of uncertainty in the value of the company. In addition, with the releasing of this type of information, besides 
reducing informational asymmetry, managers signal to the market their ability to identify, measure, and manage the risk, making it viable to capture more resources and for investors to more efficiently value the firm. Despite the above, Moumen et al. (2015) explain that even with the relevance given to the theme of risk disclosure, this field of study is still controversial as it concerns studies related to the disclosure strategy of firms. For the authors, little is known about the value relevance of the disclosure of information on risk, which supports the development of this study.

Attributing value to firms should not be based solely on current projections of accounting results, but also on flows based on "other information" related to the prospects for growth and future return not captured by the accounting. In summary, information on company assets are needed, besides the information described in the accounting statements, for adequate investment decision making (Lauretti, Kayo \& Marçal, 2009). For Solomon et al. (2000), Kimura \& Pereira (2005), and Silva et al. (2015), disclosures regarding risk and its management can fit this condition as they constitute relevant factors for estimating future cash flows.

The Ohlson model (1995) - RIV -, applied in Brazil by Lopes et al. (2007), Coelho and Braga (2008), Coelho,
Aguiar, and Lopes (2011), and Madeira and Costa (2015), enables it to be empirically tested whether "other information" derived from relevant events could aggregate future residual incomes and thus affect the current firm valuation (Coelho \& Braga, 2008; Lopes et al., 2007; Ohlson, 1995). Ohlson (1995) proposes that the value of the firm depends on (i) the value of net equity, (ii) the future residual income at present value, and (iii) the future cash flows derived from "other information" not yet captured by the accounting process due to conservatism. This study seeks to verify the relevance of the disclosure of risk and its management as a variable for carrying out company valuations. The Ohlson model (1995) explains the "other information" variable in the format of equation 1.

$$
P_{t}=\alpha_{0}+y_{t}+\alpha_{1} x_{t}^{a}+\alpha_{2} v_{t}^{a}+\varepsilon_{t}
$$

in which $P_{t}$ is the value of the firm, $y_{t}$ is net equity, $x_{t}^{a}$ represents abnormal income, and $v_{t}^{a}$ corresponds to other information. As equation 1 is a linear function, the other terms refer to the intercept of the straight line of the regression and to the error term. In conformity with the Ohlson model (1995), abnormal income $\left(x_{t}^{a}\right)$ are estimated via equation 2 .

$$
x_{t}^{a}=\text { Net Income }_{t}-\text { Net Equity } \text { In-1 }_{t} \cdot i_{t}
$$

in which $i_{t}$ is the proxy for the risk free interest rate for the period, that is, the basic remuneration of the firm's effort to beat the market in terms of return.

According to the LID assumption, there is a link between the persistence of the current accounting information and future residual incomes. Thus, the market value of a firm must be a dependent variable of expected abnormal future results related with "other information" not specified in the model (Coelho \& Braga, 2008; Lopes et al., 2007; Ohlson, 1995). The model is also based on the assumptions that (i) the value of the firm is equal to the present value of the expected dividends; and that (ii) the dividends reduce the value of net equity without affecting current earnings (Ohlson, 1995).

The interlocution between the object of study and the analysis of the informational relevance leads to the hypothesis that the information disclosed by firms that report on risks and their management could have a favorable impact on investor decision making. With the disclosure, in this specific case, of information on risk and its management by firms, it is possible to obtain lower cost of capital and with this maximize the value of the firm.
This is because the company avoids the adverse selection derived from the impossibility that the investor has of observing the adequacy of the manager's behavior that aims to maximize company value. With this, there would be greater market efficiency concerning the allocation of resources between economic agents (Akerlof, 1970; Moumen et al., 2015; Sunder, 2014), which is what is expected from this study.

Risk management can be understood as part of the governance structure and its disclosure contributes to minimizing informational asymmetry between manager and investor, since it makes public the administration of crucial processes for predicting future actions in companies, even in the selection of measures that reduce or eliminate the uncertainties that can affect future cash flows. So, it is assumed that risk management must be important for the same reasons listed by Moumen et al. (2015) when they discussed the relevance of risk disclosure. Risk management refers to identifying factors that can cause adverse financial consequences for firms, but also to establishing measures that can prevent, or even minimize, negative effects on company value. 
Managers and investors know that the former hold information that the latter do not, and informational asymmetry is therefore smoothed by disclosure. In light of this, due to the discretion and knowing that managers decide on which information will be disclosed, beyond the regulatory and legal requirements, the disclosure can affect the stakeholders' investment strategies, giving them bargaining power (Sunder, 2014). Complementarily, Bertomeu, Beyer, and Dye (2011) indicate that the disclosure policy determines the advantage of the information in the decision making, the loss related to the investments, and also the firms' cost of capital. For Abraham and Shrives (2014), disclosure regarding risk can be influenced by institutional factors and by ownership costs, which would reduce the relevance of the disclosure.

It so happens that when a company chooses a more comprehensive or less restrictive disclosure policy, the manager must endure more monitoring from the internal and external parties interested in the business (Chung et al., 2015). In accordance with this reasoning, theoretically, firms with a high value would have more incentives to reduce informational asymmetry, besides mitigating the risks of adverse selection, which would avoid a discount in the value of the firm (Chen, Cheng, Gong \& Tan, 2014). In summary, via their disclosure policy, managers signal to the market whether the firm is a "good lemon" or a "bad lemon" (Akerlof, 1970), minimizing adverse selection risks derived from informational asymmetry. In rational conditions, managers make good decisions or release "good signs" to the market because they are evaluated based on their decisions and on the disclosure, including that related to the risk factors (Dervishi \& Kadriu, 2014; Elshandidy et al., 2013).

Kimura and Pereira (2005) argue and Miihkinen (2013) shows that the quality of the disclosure of risk and its management tends to have a negative relationship with informational asymmetry. However, knowing that the disclosure could become symbolic depending on managers' behavior (Abraham \& Shrives, 2014), the establishment of rules could increase the quality of the disclosure regarding risk (Miihkinen, 2012).

The relationship between disclosure and company valuations is supported empirically and demonstrated in the studies by Chen et al. (2014) and Chung et al. (2015). The market tends to react positively to disclosure, but it should be highlighted that the type of information released can have an differential impact on firm value (Miller, 2002), since disclosure is composed of a broad spectrum of information that determines its informative value (Ball \& Brown, 1968), and is relevant for investors as it alters their expectations regarding decision making (Beaver,
1968). The design proposed in this study is coherent with the gap involving the near absence of studies that have examined the value relevance of the disclosure of risks and their management, which reinforces the position that the evidence presented is still in its infancy (Moumen et al., 2015).

Given the relevance of the contribution of the disclosure of information on risk factors and the management of risk factors for decision making in companies, various studies have been developed within this scope (Alves \& Matias, 2014; Linsley \& Shrives, 2006; Silva et al., 2015). This study reports a summary of the findings presented by these investigations. In general, these studies have sought to characterize the reporting on risk and its management in companies with regards to its content (risk factors and management tools applied). Disclosure theory is used in most of the studies, directly or indirectly, to explain how this type of disclosure contributes to influencing decision making and generating value.

In the study by Solomon et al. (2000), an investigation was carried out regarding the direction of policies and practices related to risk management in investment funds in the United Kingdom. From the perception of 97 managers, obtained via a survey, the authors concluded that almost a third of the interviewees accepted the relevance of the disclosure of risk to obtain greater accuracy when deciding on investment options. In this study, the contribution of risk management and disclosure stand out as tools of corporate governance.

Beretta and Bozzolan (2004) investigated the reporting on risk in the annual reports of 85 non-financial firms listed in the "traditional market" of the Italian stock exchange. With the application of a proposed framework for analyzing the disclosure, different information was identified in this companies that was characterized based on various aspects, including: financial, corporate, technological, strategic, environmental (legal, political, economic, and others), the perspective signaled by the information (favorable, neutral, unfavorable), the measures taken, and the external orientation (decisions, actions, programs, and current scenario). The study also examined whether the size and the sector affected this disclosure, with no such relationships being found.

The studies by Abraham and Cox (2007) and Dobler (2008) were concerned with the determinants of the disclosure of risk. While in the study from Abraham and Cox (2007) evidence shows that the reporting of this information, in the 100 companies that make up the FTSE 100 index, was influenced by the governance, size, sector, and individual risk of the firms, ownership concentration, double listing, and by the regulatory apparatus, Dobler 
(2008) concludes that there are no sufficient incentives for the disclosure of risk by managers, which omits it, limiting the informative power of the companies' reports, even in environments subject to regulation. The study from Elshandidy et al. (2013) also laid out the relationship between the level of risk and the disclosure of risk in companies in the United Kingdom, with this also being influenced by size, governance, and auditing, among other factors that are internal and external to the firm.

Jorion (2002) and Lim and Tan (2007) verified the relationship between the disclosure of the quantitative measure of the value attributed to the risk (value-at-risk VAR) and the performance of financial and non-financial companies, respectively. Disclosure of the measure is obligatory and reflects the greatness of the potential loss derived from market risks. Jorion (2002) analyzed eight banks between 1995 and 1999 and concludes that the measure was informative and explained the variability of the banks' revenues. Lim and Tan (2007) evaluated 81 companies between 1997 and 2002 and concluded that high disclosed risk measures were related with low returns and high levels of variability in the price of shares.

Linsley and Shrives (2006) unite the aims of the studies from Beretta and Bozzolan (2004) and Abraham and Cox (2007), as they characterize the disclosure of risk and examine what factors determine this reporting. In the annual reports of 76 firms in the United Kingdom, information in the categories of financial, operational, and strategic risk was obtained. It was concluded that there was a predominance of non-monetary, good, and forwardlooking information. Regarding the determinants, the size of the firms (bigger companies disclose more because their visibility and their portfolio of stakeholders are bigger) and the risk of the environment where they operate (improvement in the investor's perception in relation to the intrinsic risk and to the effort of the managers in adequate risk management) affected this type of disclosure.

Cornaggia (2013) analyzed risk management in the context of North American agricultural producers. Evidence was obtained that risk management was positively related with increased productivity, especially when there was a combination of risk management and diversification among producers. The relationship between risk management and productivity improved in countries where the access to sources of funding was greater. For Cornaggia (2013), his work helps to clarify the effects of risk management in obtaining favorable results and accessibility to sources of funding. In this case, the condition of reducing the cost of capital derived from the actions to mitigate the risks of the business stands out.

The study from Moumen et al. (2015), which is the only one identified in the literature that specifically examines the value relevance of the disclosure of risk [others were highlighted, such as Jorion (2002), Lim and Tan (2007), Lopes et al. (2007), Coelho and Braga (2008), Coelho et al. (2011), Madeira and Costa (2015), examining the relationship between "other information" and the value of firms, but not for the disclosure of risk and its management], uses the index proposed by Linsley and Shrives (2006), with 32 disclosure items, applied to annual reports of 809 observations, between 2007 and 2009. The authors observed that this type of disclosure is relevant for predicting changes in company results, and that this information is important for investor decision making. Moumen et al. (2015) claimed to have obtained the first evidence of the utility of the disclosure of risk in annual reports.

The attention of studies in Brazil is similar to the proposals of the international studies, giving descriptive and qualitative focus to the disclosure of information regarding risk and its management. In the studies from Carvalho et al. (2004), Cherobim and Alves (2006), Peleias et al. (2007), and Alves and Cherobim (2009), financial companies are examined and it is concluded that, in general, (regulatory) disclosure was not satisfactory. In summary, it was found that the disclosure was better in foreign firms; the reporting on the impacts of the risk factors on performance was not clear and the information was considered insufficient to meet the informational demands of investors and stakeholders. The conclusion is consistent with the position of Beretta and Bozzolan (2004), who indicate this evidence as being common in various studies on the reporting of risk.

Fernandes et al. (2010) and Brittes, Salles-Filho, and Pfitzner (2015) studied the risks of the sectors and of the regulation, respectively, in the electrical energy sector. Brittes et al. (2015) found that regulatory imperatives can expose companies to risks that must be combated based on the adequacy of the management of the sources of uncertainty. Corroborating previous studies, Fernandes et al. (2010) concluded that the disclosure of risks is unsatisfactory for decision making, but in relation to public offerings of securities in the capital market.

Cardoso et al. (2004), Zonatto and Beuren (2009), Beuren et al. (2011), and Alves and Graça (2013) concluded that the disclosure regarding risk and its management 
is not uniformized. In addition, different types of risk are reported by companies in financial statements (market, strategic, financial, and operational, among others). These authors also stress that various aspects lack discussion in the field of studies on disclosure of risk and its management (differences in quality of disclosure, influence of cultural factors, and strategies inherent to managers in the discretion and the relationship between disclosure and market efficiency).

This study differentiates itself from the others since studies were not observed that examined the value relevance of the information disclosed regarding risk and its management, the exception being Moumen et al. (2015), although they did not consider risk management in their analysis. The use of the Ohlson model (1995) is another difference, examining the role of "other information" in valuing Brazilian companies.

Thus, based on the theoretical framework presented and discussed, the disclosure of information regarding risk and its management, by contributing to a reduction in information asymmetry, would affect a company's valuation in the perception of its funding agents. With the disclosure of attitudes involving risk management, a proposal for mitigating uncertainty and a commitment to maximizing company value are signaled to the market. This practice, in theory, would mean the company took advantage of market opportunities not accessible to competitors, leading it to the obtainment of competitive advantages. It is also argued that the disclosure of risks and of the measures for their management enable the investor to more accurately identify the impacts that revealed risk factors can have on future cash flows and on company valuation.
Thus, considering the informative capacity of the disclosure in financial statements regarding risk and risk management in "other information" for pricing assets (Amorin et al., 2012; Chen et al., 2014; Chung et al., 2015; Cornaggia, 2013; Elshandidy et al., 2013; Fernandes et al., 2010; Kimura \& Pereira, 2005; Linsley \& Shrives, 2006; Moumen et al., 2015; Ohlson, 1995; Solomon et al., 2000; Silva et al., 2015), the following hypotheses are raised:

\begin{abstract}
$\mathrm{H}_{1}$ : the disclosure of risk factors associated with the business of a firm is value relevant in the perception of investors in the company valuation process in a statistically significant way; $\mathrm{H}_{2}$ : disclosure regarding the existence of a specific body for risk management in firms is value relevant in the perception of investors in the company valuation process in a statistically significant way.
\end{abstract}

In relation to hypothesis $\mathrm{H}_{1}$, a higher level of disclosure of risk factors is expected to lead investors to improve their firm valuations. It is assumed that investors choose to invest resources based on a broad set of information that help in estimating future cash flows, instead to deciding with a lower level of disclosure or no reported information. In relation to hypothesis $\mathrm{H}_{2}$, information about the existence of a body in the administrative structure engaged in risk management is expected to signal greater confidence about the continuity of a business and about the relevance of disclosing risk factors. The non-rejection of the hypotheses would imply that the accounting data in themselves do not explain the whole company valuation process; the existence of other information would alter the valuation, assuming the assumption of the LID, included in the Ohlson model (1995).

\section{METHODOLOGICAL PROCEDURES}

The population of the study was made up of the 508 firms listed on the São Paulo Stock, Commodities, and Futures Exchange (BM\&FBOVESPA) on the date of the data collection (November $27^{\text {th }}$ of 2015). Based on a finite population, the sample size $(n)$ was calculated considering a 95\% confidence level, sample size maximization, and a $5 \%$ sampling error. This resulted in an estimated sample of 219 randomly selected firms. Of these, companies were excluded that (i) had no market value available in the Economatica ${ }^{\oplus}$ database; (ii) had no accessible financial statements in the BM\&FBOVESPA; (iii) presented negative net equity, all this referring to the analysis period (2012-2014). After the exclusions, 100 companies (300 firm-year observations) remained; to process the test model and other statistics, the share with the highest trading liquidity, according to Economatica ${ }^{\circledR}$, was selected.

Regarding the period referred to, its relevance stands out due it covering part of the time horizon marked by the economic recession in Brazil, starting in 2009 and worsening in 2015 (Martins \& Paulo, 2016). This is because with the integration between the markets economic environments characterized like this could interfere with 
the disclosure and information asymmetry, affecting the pricing of the firms' assets via investor perception (Bergmann, Securato, Savoia \& Contani, 2015; Martins \& Paulo, 2016).
To test the hypothesis that information regarding risk and its management may not be fully contemplated in earnings, but may be reflected in future results, the Ohlson model (1995) was used, as shown in equation 3.

$$
P_{t}=\alpha_{0}+\alpha_{1} N E_{t}+\alpha_{2} A I_{t}+\alpha_{3} \operatorname{RiskInf}_{t}+\alpha_{4} \operatorname{RiskMan}_{t}+\varepsilon_{t}
$$

in which $P_{t}$ is the natural logarithm of the market value of the firms (see Economatica ${ }^{\circledR}$ ), $N E_{t}$ is the natural logarithm of net equity (see financial statements), $A I_{t}$ is the abnormal income calculated in accordance with equation 2 , scaled by $N E_{t-1}$, with the proxy for the risk free interest rate being the Special Settlement and Custody System (Selic) suggested by Lopes et al. (2007) and applied in Madeira and Costa (2015), RiskInf is the index of the volume of disclosure of risk factors, and RiskMan ${ }_{t}$ is the disclosure of the existence of a risk management entity, with a dummy with 1 for its existence and 0 otherwise.

The disclosure regarding risk factors was observed based on the "risk factors that can influence investment decisions" reported by the firms in the Reference Forms, in accordance with CVM Instruction n. 480 (CVM, 2009). This instruction requires the companies to disclose risk factors linked to (i) issuer; (ii) controller; (iii) shareholders; (iv) controlled parties; (v) suppliers; (vi) customers; (vii) sectors; (viii) regulation; and (ix) operations in foreign countries, described in Item 4.1 of the Reference Form - Description - Risk Factors.

The measurement of the variable was carried out in the following way: carrying out the firm characterization of the risk factors in the Reference Form, or if there was detail on the reason the information had been omitted, one of nine possible scores was attributed to each risk factor, and 0 otherwise. For the purposes of including equation 3 in the model, the mean of the company score was chosen, considering the nine factors, with 0 being the minimum score and 1 being the maximum, thus creating an "index" for the disclosure of risk factors.

In addition, an individualized value relevance analysis was chosen for each one of the nine risk factors, with the RiskInf $_{t}$ variable being transformed into nine dummies, with 1 for disclosure of the factor and 0 otherwise. The analysis is warranted because even with theoretical and empirical evidence of the impact of disclosure on the company valuation process (Chen et al., 2014; Chung et al., 2015), there are still caveats, given that the type of information reported could define the direction of this relationship (Miller, 2002). Accepting this prerogative, concerning the disclosure regarding risk, is not only prudent as different "categories" of this type of disclosure are referred to in the studies from Beretta and Bozzolan (2004), Cardoso et al. (2004), Linsley and Shrives (2006), Zonatto and Beuren (2009), Beuren et al. (2011), and Alves and Graça (2013).

As for the disclosure regarding the risk management in a firm, this was observed in the companies' Reference Forms, in Item 12.1 - Administrative Structure, in which the composition of the administration and the bodies that help in the management are described. The established structure with the responsibility for managing risks related to the business was sought. When there was risk management, 1 was attributed, and 0 otherwise.

The informational relevance was verified via the coefficients of the variables for disclosure of risk and risk management when statistically significant. All the financial data needed for the development of the study were collected from the standardized financial statements of the companies available from the BM\&FBOVESPA website. The estimation of model 3 was carried out with a panel data regression, adopting the modality indicated by the Breusch-Pagan and Hausman tests applied for each process; robust modeling was also used. The data were "winsorized" by applying the observations contained at the extremities of the distribution, covering $5 \%$ in each tail related to the continuous variables. It should be mentioned that this procedure increased the consistency of the coefficients of the model, especially in relation to the abnormal return. 


\section{RESULTS}

\subsection{Effects of Disclosure about Risk and its Management on Firm Value}

Before the analysis of the relevance itself, Table 1 shows the descriptive statistics of the variables considered in the value relevance model.

Table 1

Descriptive statistics of the variables used in the research

\begin{tabular}{|c|c|c|c|c|c|}
\hline Descriptive statistics & Period & $P_{t}$ & $N E_{t}$ & $A I_{t}$ & RiskInf $_{t}$ \\
\hline \multirow{4}{*}{ Mean } & 2012 & 14.2659 & 13.8864 & 0.0131 & 0.9033 \\
\hline & 2013 & 14.2373 & 13.9211 & 0.0011 & 0.9033 \\
\hline & 2014 & 14.0206 & 13.9482 & -0.0460 & 0.9111 \\
\hline & 2012-2014 & 14.1746 & 13.9186 & -0.0106 & 0.9059 \\
\hline \multirow{4}{*}{ Standard deviation } & 2012 & 1.9013 & 1.8441 & 0.2416 & 0.2117 \\
\hline & 2013 & 1.9042 & 1.8825 & 0.2269 & 0.2146 \\
\hline & 2014 & 2.0463 & 1.9543 & 0.2068 & 0.2065 \\
\hline & 2012-2014 & 1.9483 & 1.8880 & 0.2263 & 0.2103 \\
\hline \multirow{4}{*}{ Minimum } & 2012 & 10.7699 & 7.6643 & -0.7712 & 0.0000 \\
\hline & 2013 & 10.8366 & 7.8095 & -0.8320 & 0.0000 \\
\hline & 2014 & 10.3835 & 7.6653 & -1.0523 & 0.0000 \\
\hline & 2012-2014 & 10.3835 & 7.6643 & -1.0523 & 0.0000 \\
\hline \multirow{4}{*}{ Maximum } & 2012 & 19.3562 & 19.6169 & 1.3739 & 1.0000 \\
\hline & 2013 & 19.1847 & 19.6715 & 0.7913 & 1.0000 \\
\hline & 2014 & 19.0253 & 19.5544 & 0.6795 & 1.0000 \\
\hline & 2012-2014 & 19.3562 & 19.6715 & 1.3739 & 1.0000 \\
\hline \multirow{4}{*}{ Median } & 2012 & 14.2958 & 13.9345 & 0.0056 & 1.0000 \\
\hline & 2013 & 14.2355 & 13.9960 & 0.0142 & 1.0000 \\
\hline & 2014 & 13.7637 & 14.0602 & -0.0311 & 1.0000 \\
\hline & 2012-2014 & 14.1542 & 14.0068 & -0.0071 & 1.0000 \\
\hline
\end{tabular}

Note: the variables are described in the text.

Source: elaborated by the authors.

Based on Table 1, it is perceived that the means for the value of the companies and the abnormal income reduced in the period, perhaps due to the effects of the economic recession and low optimism in the market. In contrast, the average net equity increased. The disclosure of risk factors was shown to be satisfactory in the sample. Regarding risk management, 71 observations had information about the existence of this specific administrative body in the firms, representing $24 \%$ of the total. The firms with risk management have better results for the disclosure of risk factors (mean: 0.9390 against 0.8957; amplitude: 0.4444 against 1.000 ; standard deviation: 0.1185 against 0.2307 ), which may signal the impact of risk management on disclosure. As a dichotomous variable is concerned, risk management was not included in the descriptive analysis.

The results indicated in Table 2 reproduce the processing of four formulations of equation 3 and signal that there are different degrees of relevance of the accounting information and of the disclosure of information about risk factors and their management in the firm valuation process in the Brazilian stock market. 
Table 2

Value relevance and disclosure of risk

\begin{tabular}{|c|c|c|c|c|}
\hline \multicolumn{5}{|c|}{$P_{t}=\alpha_{0}+\alpha_{1} N E_{t}+\alpha_{2} A I_{t}+\alpha_{3} \operatorname{RiskInf}_{t}+\alpha_{4}$ RiskMan $_{t}+\varepsilon_{t}$} \\
\hline Parâmetros & $\mathbf{a}$ & b & c & d \\
\hline$\alpha_{0}$ & $9.73^{* * *}$ & $9.90^{* * *}$ & $2.23 * * *$ & $2.60 * * *$ \\
\hline$\alpha_{1}$ & $0.32^{* * *}$ & $0.35^{* * *}$ & $0.86^{* * *}$ & $0.87^{* * *}$ \\
\hline$\alpha_{2}$ & $0.99^{* * *}$ & $1.06^{* * *}$ & $1.36^{* * *}$ & $1.40^{* * *}$ \\
\hline$\alpha_{3}$ & - & $-0.72 * * *$ & - & -0.56 \\
\hline$\alpha_{4}$ & - & - & 0.08 & 0.10 \\
\hline F statistic & $9.91^{* * *}$ & $11.96^{* * *}$ & $256.15^{* * *}$ & $275.09^{* * *}$ \\
\hline $\mathrm{R}^{2}$ & 0.1263 & 0.1623 & $0.7847^{*}$ & $0.7798^{*}$ \\
\hline Estimation & Fixed effects & Fixed effects & Random effects & Random effects \\
\hline Observations (n) & 300 & 300 & 300 & 300 \\
\hline
\end{tabular}

$a=$ residual income valuation $(R I V) ; b=$ risk factors; $c=$ risk management; $d=$ complete formulation.

$*=R^{2}$ for estimation with fixed effects is 0.1374 and 0.1887 , althought the Chow, Breusch-Pagan, and Hausman tests lead to its rejection; ${ }^{* * *}=1 \%$ level of significance.

Source: elaborated by the authors.

The first column confirms the proposal from Ohlson (1995) that abnormal income are relevant for explaining investors' and shareholders' company valuations; moreover, the assumption of the model is fulfilled, since the coefficient related to income is positive and lower than 1; that is, the accounting aggregates have informational value and net equity and residual incomes show significance.

On the other hand, it is perceived that introducing the variables related to other information, despite raising the coefficient of determination of the regressions, disrupts the way the coefficients are interpreted, especially with regards to the processes in columns $\mathrm{c}$ and $\mathrm{d}$, given that in these cases there is significance regarding the variables representative of any dimension of risk, leading the coefficients concerning abnormal income to violate the assumptions of RIV.

However, the disclosure regarding the set of different risk factors would be contributing to the firm share pricing process, with this not being observed with respect to the information about the body for managing the risk factors. So, in the case of column $b$ the information on risk is significant and consistent with the value relevance process; in truth, due to its negative nature, the weight of the abnormal income is softened in the valuation.

This result corroborates the positions derived from the discussion or from the empirical verification in the studies from Solomon et al. (2000), Beretta and Bozzolan (2004), Linsley and Shrives (2006), Alves and Matias (2014), Moumen et al. (2015), and Silva et al. (2015). All argue that disclosure regarding risk is prioritized in the firm valuation process.
However, it should be noted that none of the studies mentioned studied the context of the Brazilian stock market, which leads to questions about the utility and quality of this type of disclosure. In addition, the studies mentioned consider the information regarding risk, when reported, to be an element that helps in valuations.

In studies that have segregated the economic sector, such as Carvalho et al. (2004), Cherobim and Alves (2006), Peleias et al. (2007), Alves and Cherobim (2009), and Fernandes et al. (2010), the evidence of relevance of the disclosure of risk is not corroborated. All investigated regulated segments, the financial one, and the electrical energy one, concluding that the reporting of risk was not satisfactory and marked by low quality and little relevance.

It is prudent to mention that the rate of disclosure of risk factors is high, with most of the companies disclosing with regards to risk in accentuated volumes. However, it was perceived that the informational content present in the firms' reports practically did not vary in the three years of analysis, removing the variability in the perception of the investors and perhaps explaining the negative relationship, contrary to expectations. The firms in Brazil, as practice, repeat the reporting of sources of risk, which does not guarantee an adequate evaluation of the securities.

The disclosure regarding risk management presented a coefficient that was statistically equal to 0 , which indicates the inexistence of informational relevance of this type of reporting in the Brazilian stock market. This evidence goes against Solomon et al. (2000), Fernandes et al. (2010), and Cornaggia (2013), who study or discuss the contribution, even if potential, of risk management as a corporate governance tool for firms. 
Other studies could investigate how the establishment of this body in the administrative structure acts in solving agency conflicts and in increasing accuracy in the investor decision-making process in the Brazilian setting, which was not addressed in this study. What is expected from risk management is the ability to identify and mitigate elements capable of maximizing negative effects on firm equity. Despite the prerogative, risk management as reported information was not shown to be informative.

The finding may raise questions about the contribution of the Brazilian institutional environment with regards to the value relevance of the accounting aggregates. For this, other studies could consider this aspect. Assuming that certain characteristics of the economic hypothesis can be generators of differences in perception and utility of the disclosure (Bergmann et al., 2015; Lopes et al.,
2007; Martins \& Paulo, 2016), the Brazilian stock market may not attribute relevance to the information on risk management established due to inefficiencies in this market.

Only $24 \%$ of the observations refer to the existence of risk management established as a management assisting entity. In these conditions, there would be reasons to believe that risk management would not be capable of affecting the value of the business. It is noted that the establishment of risk management is not obligatory. Even considering its importance, as according to the portion of studies provided here, information about the existence of risk management did not prove to be relevant within the context of valuing firms.

Results alluding to the informational relevance of each risk factor were also highlighted, as shown in Table 3.

Table 3

Value relevance of the disclosure of risk factors

\begin{tabular}{|c|c|c|c|c|c|c|}
\hline \multicolumn{7}{|c|}{$P_{t}=\alpha_{0}+\alpha_{1} N E_{t}+\alpha_{2} A I_{t}+\alpha_{3}$ Risk Inf $f_{t}+\varepsilon_{t}$} \\
\hline Factors & $\alpha_{0}$ & $\alpha_{1}$ & $\alpha_{2}$ & $\alpha_{3}$ & F statistic & $\mathbf{R}^{2}$ \\
\hline 1 & $9.96^{* * *}$ & $0.38^{* * *}$ & $0.99 * * *$ & $-1.06^{* * *}$ & Absent $^{\mathrm{a}}$ & 0.1592 \\
\hline 2 & $9.83^{* * *}$ & $0.35^{* * *}$ & $1.00^{* * *}$ & $-0.64^{* *}$ & $9.42^{* * *}$ & 0.1509 \\
\hline 3 & $9.88^{* * *}$ & $0.33 * * *$ & $1.04 * * *$ & $-0.28^{*}$ & $10.43 * * *$ & 0.1427 \\
\hline 4 & $9.90^{* * *}$ & $0.33^{* * *}$ & $1.06^{* * *}$ & $-0.30^{* *}$ & $10.76^{* * *}$ & 0.1458 \\
\hline 5 & $9.70^{* * *}$ & $0.36^{* * *}$ & $1.09 * * *$ & $-0.56^{* *}$ & $11.31^{* * *}$ & 0.1641 \\
\hline 6 & $9.73^{* * *}$ & $0.35^{* * *}$ & $1.06^{* * *}$ & $-0.48^{* *}$ & $10.86^{* * *}$ & 0.1539 \\
\hline 7 & $9.85^{* * *}$ & $0.35^{* * *}$ & $1.00 * * *$ & $-0.63^{* *}$ & $9.42 * * *$ & 0.1509 \\
\hline 8 & $9.83 * * *$ & $0.35^{* * *}$ & $1.00^{* * *}$ & $-0.63^{* *}$ & $9.42^{* * *}$ & 0.1509 \\
\hline 9 & $9.83^{* * *}$ & $0.33^{* * *}$ & $1.01^{* * *}$ & $-0.30^{*}$ & $9.65^{* * *}$ & 0.1428 \\
\hline
\end{tabular}

Notes: $n$ = 300; estimation of the models by fixed effects; factor 1 (issuer), factor (controller), factor 3 (shareholders), factor 4 (controlled parties), factor 5 (suppliers), factor 6 (customers), factor 7 (sectors), factor 8 (regulation), factor 9 (operations in foreign countries). $\mathrm{a}=$ the results of the $F$ estimation are absent in the model with the insertion of the White matrix, but significant to $1 \%$ when there is not insertion.

$* * *, * *, * 1,5$, and $10 \%$ significance, respectively;

Source: elaborated by the authors.

It is perceived that the disclosure of each risk factor is also significant and relevant for the valuation process. More than $97 \%$ of the observations reported risks related to the issuer (factor 1), which may explain the absence of the F statistic in this robust model. In this field, the firms indicated aspects of indebtedness, strategic definition, relationship with economic agents, operational capacity, corruption, competition, maintaining their human capital, and infrastructure.

Factors 2, 7, and 8 (controller, sector, and regulation) stand out with the greatest value relevance. Information on risks related to the shareholders and to the controlled parties, represented by factors 3 and 4, has lower informative value for pricing. Thus, it is shown that the different types of risk generate different expectations in the valuation, suggesting that the type of risk may be a determinant for the attribution of value and for decision making. This supports the studies by Miller (2002), Beretta and Bozzolan (2004), Cardoso et al. (2004), Linsley and Shrives (2006), Zonatto and Beuren (2009), Fernandes et al. (2010), Beuren et al. (2011), Alves and Graça (2013), and Brittes et al. (2015). These studies suggest that the type of disclosure about risk has informative value. 


\subsection{Discussion}

The findings reinforced the idea that investors not only lack, but use supplementary information to that disclosed by accounting statements (Lauretti et al., 2009) when pricing securities, confirming the contribution of the RIV model proposed by Ohlson (1995). The identification of evidence that suggests the utility of disclosure associated with the risk factors related to a business leads it to be believed that the Brazilian capital market evaluates the broad spectrum of available information, choosing the elements that have informational relevance and are therefore capable of altering decision-making expectations (Ball \& Brown, 1968; Beaver, 1968).

In contrast, it can be verified that the type of disclosure (Miller, 2002), besides its nature or purpose, denotes different interpretations by investors. This aspect is raised as it should be remembered that inferences about value relevance are essentially different in the comparisons of information about risk factors and about their management. While the latter did not indicate informational relevance, the volume of information about risk factors, as well as the type of reporting related to risk, indicated value relevance.

The benefit of reducing asymmetry should be evaluated with care according to the type of information reported, which is what the results presented demonstrate. Managers signal to investors their ability to identify, measure, and manage risk with this information. With this, giving them bargaining power (Sunder, 2014), they determine the advantage of this information in decision making (Bertomeu et al., 2011). In this study, it is indicated that if the reduction in asymmetry involves the reporting of risk, the firm valuation tends to be lower in the market. This could come about because the investor is pessimistic and chooses to anticipate the risks in the valuation, thus not overvaluing the business. Another reason would be the invariability observed in the disclosure of the risk factors and the null value relevance of the risk management.

Lopes et al. (2007), Abraham and Shrives (2014), Bergmann et al. (2015), and Martins and Paulo (2016) stress that the institutional environment, besides firm characteristics, such as ownership costs, can interfere in the relevance of the disclosure. The disclosure of risk factors is shown to be a value reducer, leading the market to demand a higher premium for these firms' securities. A reasonable explanation is derived from the characteristics of the Brazilian market: credit-based, a strong link between tax and accounting aspects, government influence in the establishment of rules (mitigated due to the accounting convergence with the international standards), and influence of Roman law in the elaboration of the legislation (Lopes et al., 2007). These factors reign over the accounting, the informational relevance, and the disclosure, and perhaps explain why risk management, which is present in very few firms, has an inexistent reflection on value.

The evidence provided corroborates the affirmation that the accounting information represents an important useful variable for estimating companies' future cash flows (Amorin et al., 2012) and converges with the concept that investors make their decisions to invest resources in firms based on expectations about the materialization of future results (Fisher \& Hall, 1969), according to disclosure theory. Firms, represented by their management, need to send out "good signs" to the market. Thus, the disclosure of risk factors represents this "good sign", in comparison with the absence of disclosure (Akerlof, 1970; Dervishi \& Kadriu, 2014; Elshandidy et al., 2013), given that they contribute to the formation of company value.

\section{CONCLUSION}

The study has achieved its objective, by showing the impact of information on risk factors and on the existence of a risk management body, revealed in accounting statements for the company valuation process in Brazil, in the perception of investors. It was concluded that the type of disclosure studied interferes in the attribution of value to a business, which suggests that other information, not recognized in the accounting process for valuing firms, in this case associated with information about risk factors and about risk management bodies, interferes in the valuation process in the capital market, in addition to the strictly accounting valuation.
Of the hypotheses raised, the one that suggests the relevance of the reporting corresponding to the informational volume about risk factors in the process of valuing securities, is not rejected. It was also found that, individually, the information on risk factors is relevant for valuing firms to different degrees. As for the hypothesis that suggests value relevance of information alluding to risk management bodies, this was rejected. The results indicated that the disclosure of risk factors moderates the overvaluation of company shares and that the information on the establishment of a specific body for risk management is not taken into account by investors 
for pricing securities. Thus, alternatives could be explored in other studies in the future, such as the interactive effect between the disclosure of risk factors and a risk management body and the accounting numbers, thus helping to explain the relevance of the purely accounting predictors.

This study has provided aspects that add to the field of investigation on disclosure, more specifically regarding the evidence associated with the risk factors considered by companies in their businesses. The multiplicity of variables described in the reports as a source of possible financially adverse effects, such as competition, political instability, global economic situation, technological development, and scarcity of resources, suggests the complexity inherent to the asset pricing process, assuming subjectivity and discretion on the part of the agents.

This could be fertile ground for studies interested in qualifying the risk factors in specific markets, helping to understand the reasons for which the disclosure regarding risk factors affects the company valuation process in Brazil, while the information concerning risk management bodies was not shown to be relevant. Managerially, the research could incentivize managers in the elaboration of reports containing greater informative quality, given that various companies were observed that, in general, repeated the information that characterized the risks to their business in the three years studied. In summary, the investor tends to reduce the value of the firm or judge the disclosure to be irrelevant, since it is invariable in the period.

The immutability of the disclosure of risk factors calls into question the effective actuation of management with regards to evaluating a business' risk factors, reliably portraying them in the reports. The other side of the coin is to assume in advance the inefficiency of the risk management, since if the disclosure does not change, it is unlikely that the sources of uncertainty for the business have remained constant over the three years studied. Thus, the market may understand that the disclosure would only reflect the raising of costs and the management's administrative and monitoring inefficiency, helping to explain the value relevance obtained in this study. In the brief descriptive analysis, it was possible to note that the reporting is a little better (on average) in those companies with an established risk management body, despite the low adherence to the establishment of this governance mechanism.

The research contributes to investigating how the disclosure practiced, the risk perceived, and the value of the firm may be related in the Brazilian market. Supports are given to question the processes of attributing value and decision making based on the disclosure of sources of uncertainty and their management in companies. This helps managers and investors with regards to the reporting and identification of information considered critical for maximizing company value.

This study is limited and understanding these restrictions is important for a better evaluation of the results explained. The following can be mentioned:

a. The measurement of the variables associated with risk (factors and management) covered only the verification of the existence of the information and did not investigate in depth the content related to the disclosure. This evidence, if explored, could contribute to the suggested analysis;

b. The econometric models constitute a short panel and can generate large differences between the estimators of the approaches with fixed and random effects. Thus, studies could be carried out that explored greater time horizons;

c. Even with the comprehensive and random initial sampling delimitation, restrictive factors inherent to the data collection stage reigned over the determination of the final sample. In this sense, raising the number of observations could give robustness to the results reached;

d. It should be remembered that any generalizations of these results and conclusions need to consider the constant characteristics in the methodological center of the study, given that they are conditioned to the approach followed in this research. New investigations could provide other perspectives when they extrapolate the limitations described.

\section{REFERENCES}

Abraham, S., \& Cox, P. (2007). Analysing the determinants of narrative risk information in UK FTSE 100 annual reports. The British Accounting Review, 39(3), 227-248.

Abraham, S., \& Shrives, P. J. (2014). Improving the relevance of risk factor disclosure in corporate annual reports. The British Accounting Review, 46(1), 91-107.
Akerlof, G. A. (1970). The market for "lemons": quality uncertainty and the market mechanism. The Quarterly Journal of Economics, 84(3) 488-500.

Alves, C. A. M., \& Cherobim, A. P. M. S. (2009). Análise do nível de divulgação do risco operacional segundo recomendações 
do comitê da Basileia: estudo em bancos do país e do exterior. Revista de Administração Mackenzie, 10(2), 57-86.

Alves, M. T. V. D., \& Graça, M. L. (2013). Divulgação de informação sobre o risco de mercado: um caso de empresas do PSI20. Revista Universo Contábil, 9(3), 163-184.

Alves, M. T., \& Matias, F. J. F. (2014). Gestão e divulgação do risco operacional e os acordos de Basileia: o caso dos maiores bancos portugueses. Revista Universo Contábil, 10(3), 172-193.

Amorin, A. L. G. C., Lima, I. S., \& Murcia, F. D-R. (2012). Análise da relação entre as informações contábeis e o risco sistemático no mercado brasileiro. Revista Contabilidade \& Finanças, 23(60), 199-211.

Ball, R., \& Brown, P. (1968). An empirical evaluation of accounting income numbers. Journal of Accounting Research, 6(2), 159-178.

Beaver, W. H. (1968). The information content of annual earnings announcements. Journal of Accounting Research, 6(1), 67-92.

Beretta, S., \& Bozzolan, S. (2004). A framework for the analysis of firm risk communication. The International Journal of Accounting, 39(3), 265-288.

Bergmann, D. R., Securato, J. R., Savoia, J. R. F., \& Contani, E. A. R. (2015). U.S. subprime financial crisis contagion on BRIC and European Union stock markets. Revista de Administração da USP, 50(2), 229-240.

Bertomeu, J., Beyer, A., \& Dye, R. (2011). Capital structure, cost of capital, and voluntary and disclosures. Forthcoming in the Accounting Review, 86(3), 857-886.

Beuren, I. M., Dallabona, L. F., \& Dani, A. C. (2011). Disclosure de informações sobre gestão de riscos e controle interno pelas empresas listadas na BM\&FBovespa. Revista de Economia e Administração, 10(1), 44-65.

Brittes, J. L. P., Salles-filho, S. L. M., \& Pfitzner, M. S. (2015). Avaliação do risco regulatório em pesquisa \& desenvolvimento no setor elétrico brasileiro. Revista de Administração Contemporânea, 19(2), 193-211.

Brown, S., Lo, K., \& Lys, T. (1999). Use of $\mathrm{R}^{2}$ in accounting research: measuring changes in value relevance over the last four decades. Journal of Accounting and Economics, 28(2), 83-115.

Cardoso, R. L., Mendonça, O. R., \& Riccio, E. L. (2004). A evolução recente da transparência dos fatores de risco nas informações contábeis: uma análise de empresas brasileiras de telecomunicações. Revista de Administração Mackenzie, 5(2), 13-35.

Carvalho, L. N. G., Trapp, A. C. G., \& Chan, B. L. (2004). Disclosure e risco operacional: uma abordagem comparativa em instituições financeiras que atuam no Brasil, na Europa e nos Estados Unidos. Revista de Administração da USP, 39(3), 264-273.

Chen, J. J., Cheng, X., Gong, S. X., \& Tan, Y. (2014). Do higher value firms voluntarily disclose more information? Evidence from China. The British Accounting Review, 46(1), 18-32.

Cherobim, A. P. M. S., \& Alves, C. A. M. (2006). Investigação sobre evidenciação do risco operacional: estudo multicaso em instituições financeiras brasileiras. Revista de Administração e Contabilidade da Unisinos, 3(2), 124-138.
Chung, H., Judge, W. Q., \& Li, Y-H. (2015). Voluntary disclosure, excess executive compensation, and firm value. Journal of Corporate Finance, 32(C), 64-90.

Coelho, A. C., Aguiar, A. B., \& Lopes, A. B. (2011). Relationship between abnormal earnings persistence, industry structure, and market share in Brazilian public firms. Brazilian Administration Review, 8(1), 48-67.

Coelho, A. C., Braga, A. (2008). Relacionamento entre persistência do lucro residual e participação de mercado em firmas de capital aberto. Revista de Contabilidade e Organizações, 2(3), 3-18.

Comissão de Valores Mobiliários. (2009). CVM Instruction 480, of December $7^{\text {th }}$ of 2009. This discusses the recording of issuers of securities accepted for trading in regulated securities markets. Retrieved from http://www.cvm.gov.br/legislacao/inst/ inst480.html

Cornaggia, J. (2013). Does risk management matter? Evidence from the U.S. agricultural industry. Journal of Financial Economics, 109(2), 419-440.

Dervishi, A., \& Kadriu, I. (2014). Decision making under the conditions of risk and uncertainty in some enterprises of Prishtina and Ferizaj. European Scientific Journal, 1(Special), 224-228.

Dobler, M. (2008). Incentives for risk reporting - A discretionary disclosure and cheap talk approach. The International Journal of Accounting, 43(2), 184-806.

Edirisinghe, C., Gupta, A., \& Roth, W. (2015, November). Risk assessment based on the analysis of the impact of contagion flow. Journal of Banking \& Finance, 60, 209-223.

Elshandidy, T., Fraser, I, \& Hussainey, K. (2013). Aggregated, voluntary, and mandatory risk disclosure incentives: evidence from UK FTSE all-share companies. International Review of Financial Analysis, 30(2013), 320-333.

Fernandes, F. C., Souza, J. A. L., \& Faria, A. C. (2010). Evidenciação de riscos e captação de recursos no mercado de capitais: um estudo do setor de energia elétrica. Contabilidade, Gestão e Governança, 13(1), 59-73.

Fisher, I. N., \& Hall, G. R. (1969). Risk and corporate rates of returns. The Quarterly Journal of Economics, 83(1), 79-92.

Jorion, P. (2002). How informative are value-at-risk disclosures? The Accounting Review, 77(4), 911-931.

Kimura, H., \& Perera, L. C. J. (2005). Modelo de otimização da gestão do risco em empresas não financeiras. Revista Contabilidade \& Finanças, 16(37), 59-72.

Kothari, S. P. (2001). Capital markets research in accounting. Journal of Accounting and Economics, 31(1-3), 105-231.

Lauretti, C. M., Kayo, E. K., \& Marçal, E. F. (2009). A sobrerreação do mercado à informação intangível. Revista Brasileira de Finanças, 7(1), 215-236.

Lim, C. Y., \& Tan, P. M. S. (2007). Value relevance of value-at-risk disclosure. Review of Quantitative Finance and Accounting, 29(4), 353-370.

Linsley, P. M., \& Shrives, P. J. (2006). Risk reporting: a study of risk disclosures in the annual reports of UK companies. The British Accounting Review, 38(4), 387-404. 
Lopes, A. B., Sant'Anna, D. P., \& Costa, F. M. (2007). A relevância das informações contábeis na Bovespa a partir do arcabouço teórico de Ohlson: avaliação dos modelos de residual income valuation e abnormal earnings growth. Revista de Administração da USP, 42(4), 497-510.

Madeira, F. L., \& Costa, J. V., Jr. (2015). Value relevance dos outros resultados abrangentes nas companhias abertas brasileiras. Advances in Scientific and Applied Accounting, 8(2), 204-217.

Martins, O. S., \& Paulo, E. (2016). Efeitos crise e divulgação sobre a assimetria de informação no mercado acionário brasileiro. Contabilidade Vista \& Revista, 27(2), 113-133.

Miihkinen, A. (2012). What drives quality of firm risk disclosure? The impact of a national disclosure standard and reporting incentives under IFRS. The International Journal of Accounting, 47(4), 437-468.

Miihkinen, A. (2013). The usefulness of firm risk disclosures under different firm riskiness, investor-interest, and market conditions: new evidence from Finland. Advances in Accounting, incorporating Advances in International Accounting, 29(2), 312-331.

Miller, G. S. (2002). Earnings performance and discretionary disclosure. Journal of Accounting Research, 40(1), 173-204.

Moumen, N., Othman, H. B., \& Hussainey, K. (2015). The value relevance of risk disclosure in annual reports: evidence from MENA emerging markets. Research in International Business and Finance, 34(C), 177-204.
Ohlson, J. A. (1995). Earnings, book values, and dividends in equity valuation. Contemporary Accounting Research, 11(2), 661-687.

Peleias, I. R., Silva, A. J. M., Guimarães, I. C., Machado, L. S., \& Segreti, J. B. (2007). Demonstrações contábeis de bancos brasileiros: análise da evidenciação oferecida à luz do gerenciamento de riscos. Revista de Administração e Contabilidade da Unisinos, 4(1), 22-36.

Silva, M. L., Albuquerque, F. H. F., Marcelino, M. M., \& Quirós, J. T. (2015). A divulgação do risco nas demonstrações financeiras: uma análise ao anexo das sociedades não financeiras portuguesas. Revista de Educação e Pesquisa em Contabilidade, 9(3), 331-354.

Solomon, J. F., Solomon, A., Norton, S. D., \& Joseph, N. (2000). A conceptual framework for corporate risk disclosure emerging from the agenda for corporate governance reform. British Accounting Review, 32(4), 447-478.

Sunder, S. (2014). Teoria da contabilidade e do controle. São Paulo, SP: Atlas.

Terra, P. R. S., \& Lima, J. B. N. (2006). Governança corporativa e a reação do mercado de capitais à divulgação das informações contábeis. Revista Contabilidade \& Finanças, 17(42), 35-49.

Zonatto, V. C. S., \& Beuren, I. M. (2009). Evidenciação da gestão de riscos do COSO (2004) nos relatórios de administração de empresas com ADR's. Contabilidade, Gestão e Governança, $12(3), 38-54$. 